\title{
Profound Encounters: The Love Feast and the Old German Baptist Brethren
}

\author{
Tony Walsh \\ Director \\ Centre for the Study of Irish Protestantism \\ Maynooth University \\ Co Kildare, Ireland \\ Tony.Walsh@mu.ie
}

\begin{abstract}
The author uses an autoethnographic and narrative approach, based in a postpositivist research framework, to describe and explore the love feast as it is observed among the Old German Baptist Brethren. The "love feast occasion" constitutes a site of prime spiritual and communal significance for members of the group, who represent the largest Plain or Old Order expression of the Schwarzenau Brethren. The occasion, taking place over a full weekend of services, communal meals, informal time for fellowship and "Youngfolks" activities is hosted annually by each district or congregation (as well as being held at the group's Annual Meeting at Pentecost). Its essential feature is a lengthy service held on the Saturday evening that reenacts the central events of Jesus's last meal with his disciples in Jerusalem, prior to His betrayal and death. Discrete but interlinked elements of this highly ritualized service involve preparation, footwashing, a communal fellowship meal, an exchange of the holy kiss and sharing in the bread and wine of Communion. The deeply symbolic and highly ritualized event constitutes an occurrence in which members see themselves as renewing their connection with God, their mystical relationship with fellow members and with the central emphases of Brethren teaching.
\end{abstract}

Submitted April 27, 2021; accepted August 10, 2021; published October 8, 2021

https://doi.org/10.18061/jpac.v2i1.8285

Keywords: Old German Baptist Brethren, love feast, autoethnography, narrative inquiry, Pietism, Anabaptism, ritual, preparation, footwashing, Lord's Supper, holy kiss, Communion, relationship

\section{Introduction}

I arrive early ${ }^{1}$ with my hosts at the simple white clapboard meetinghouse, set in its grove of ancient trees. The parking lot is already well-filled with dark-colored vehicles. Standing by the car, I can feel the sense of vibrant expectation as groups form and re-form. The noise of excited greetings and the enthusiastic exchange of news fills the air; people seem so happy to see one another on this chilly autumn morning where white frost lingers on the grass verges of rural Indiana. Children run among the groups, arrows of pulsating color between their somberly clad elders. A constant stream of women, clutching pie dishes, head for the steep steps to the basement

${ }^{1}$ Dr. Tony Walsh was until recently a full-time member of the academic staff, and a former head at the Department of Adult and Community Education, Maynooth University, Ireland, where he continues as director of the Centre for the Study of Irish Protestantism. A licensed systemic constructivist psychotherapist and supervisor, he is editor, and co-author of a number of books on radical education, narrative and postpositivist research, interculturalism, and suicide and has ongoing research involvements in Palestine, Liberia, the United States, England, and Ireland. 
where the kitchens are located. Most are clothed in the regulation outdoor wear of black bonnets and shawls against the chill of the autumn morning. Groups of teenagers chat animatedly; those dressed in fashionable American clothing are punctuated by their peers-now church membersclad in regulation uniform: black hats and suits for the boys, long print dresses and white head coverings for the girls. Despite the cool morning, the latter have jettisoned the dark outdoor wear of their elders. The vibrant colors of the overarching maples and the bright blue of the autumnal sky provide lively foils to the somber shades beneath.

Several more black vans draw into the lot; their registration plates display origins in at least three neighboring states. Efficiently managed by a group of teenage boys, black hatted and armed with batons, they are being directed to park neatly on overflow grassland adjoining the graveyard. Elderly members, groups of older teenagers, and crowds of families disgorge from packed vehicles and head purposefully for the already chatting groups. While the Old German Baptists are spread across many states, social networks and extended family ties transcend such borders. Love feast weekends, primarily a focus for spiritual renewal, are also the delightful focus for renewing relationships and creating new connections. They are also significant occasions when young people meet up and romantic connections are forged, frequently leading to marriage.

Watching now, a little apart and at the edge of this busy crowd, I am aware of the beauty of the American autumn morning; its sharp coldness and the vibrancy of colors are so different from the damp mistiness of a mellow Irish October. I am conscious too of my dress-tweed jacket and grey pants are somber, but they do stand out as distinctive here. And I am conscious of my difference of status - that of guest and observer. Interested in Plain life for a long time, some years back presenting a paper at a conference in Indianapolis on Irish Protestantism, I had been offered the opportunity of spending a weekend with a Plain couple willing to introduce me to their world. They were Old German Baptists, and I was swiftly hooked by the group's welcome, their love of conversation and storytelling, their distinctive lifestyle, and the depth of their spirituality. Each year since then, I have had the opportunity of spending time building warm relationships with members, worshipping with various districts (congregations), and attending the group's yearly Annual Meeting. Conscious of my interest and indeed of my role as a researcher, I have been invited today to attend the love feast as an observer. (Only baptized members of the group can participate fully in the sacred rituals.) Here this morning, I am aware of my liminal status; I am an outsider but one strangely poised on a threshold, observing a different world with interest and respect. I am conscious of difference but also of real and growing friendships with many members and of their interest in the little I have written of their life. And I hope that this weekend they too will be aware of that respect; as a member of the tiny Irish Protestant minority, I am all too accustomed to brash intrusive stares and to the dismissive-or plain inaccurate-commentary of curious outsiders. Abruptly my reverie ends; a group is waving, beckoning me...I cross the frosty grass to join them.

This article explores the contours of the love feast, that central occasion so vital to the spiritual and communal life of the Old German Baptist Brethren (OGBB), a small Plain church now found 
solely in the United States. ${ }^{2}$ The group's origins draw strongly on both Anabaptist and Pietist traditions and this legacy of (occasionally contentious) emphases, together with the richness and complexity of the group's ritual life, are two of a number of distinctive features that mark the Old German Baptists as unusual among their Plain peers. ${ }^{3}$

For the Old German Baptist Brethren, the love feast is in the tradition of the early Christians' agape (i.e., unconditional, brotherly love) meal. More significantly, for the Brethren the observance ritually reenacts the various movements of Jesus's last evening with His disciples in Jerusalem's "upper room." While the love feast is not unknown among other churches, the group brings an emphasis and a unique performative intricacy to this distinctive expression of their life of faith. Each such occasion is not just an opportunity for a deepening commitment to their Lord, it is also a rich opening through which to celebrate the sense of mystical fellowship that binds them together as a fraternity.

\section{Two Distinctions}

The Old German Baptist Brethren are distinguishable from other Plain groups in a number of distinctive ways. Two of these are discussed in this piece; others will be the subject of a later article. First the "Fraternity of the Brethren" (the title often historically used by the group) continues to weave together core elements of both Pietism and Anabaptism, both formative influences in their historical emergence. In the past, historians and theologians, particularly Friedmann (1949), emphasized the divergence between the two traditions. More recently, academics have been at pains to highlight the overlap between the foundational principles of the two. Bach $(2003,28-29)$ in particular invites attention to complementarity and to areas of commonality.

At their best, the Old German Baptist Brethren seek to maintain a certain balance between these influences; they foreground (1) an emphasis on individual spiritual experience and a certain mysticism with (2) a coterminous stress on the importance of the collective and submission to the authority of the corporate body. Kraybill and Bowman $(2001,7)$ put it this way:

While Brethren sought to keep the Pietist interest in a deep almost mystical spirituality, they exchanged individualistic views of the religious life for understandings of community discernment, discipline, and correction that were much more typical of their Anabaptist neighbors.

\footnotetext{
${ }^{2}$ With particular concentrations in Ohio, Pennsylvania, Indiana, and Virginia, the Old German Baptist Brethren are found in some dozen states. Baptized membership currently amounts to around 4,000 (with a total community roll of some 20,000). A split in 2009 and another smaller division in 2021, both of which relate to the authority of Annual Meeting and to differing views on internet usage, resulted in a reduction of original numbers (by at least a third) to current levels.

${ }^{3}$ I intend to explore other characteristics that mark the Old German Baptist Brethren as distinctive among Plain groups in a forthcoming article.
} 
It would be invidious to suggest that the maintenance of this balance is always a straightforward or easy task. Elements of both formative influences find a ready expression in the love feast. Here, participants are explicitly challenged through the preaching but even more potently, if more implicitly, through the detailed symbolism of the ritual enactments in which they are engaged. There is a simultaneous stress on individual self-examination and accountability, on personal spiritual recommitment and on an enhanced holiness of living. There is also, however, a coterminous reiteration of the assumptive world of the Fraternity and its boundaries. Church membership is emphasized as a clearly circumscribed entity and, moreover, the bonds of that fellowship are considered sacred. Lines of demarcation between those who belong and those who do not are clearly drawn. Nonconformity to the standards and behaviors of the world is constantly reiterated, as is submission to the brotherhood.

Second, the group lays a strong emphasis on ritual, unusual among their Old Order peers. This is evident in their rites of baptism and anointing as well as in Sunday services of worship, but it is most especially apparent when they meet for the love feast. While, on the one hand, there is a starkness and simplicity in the occasion's observance among the OGBB, the simultaneous level of ritualized complexity is at times reminiscent of the detail and solemnity of Orthodox or Anglo- or Tridentine Rite Roman Catholic observance. Each action is not just detailed but freighted too with spiritual meaning. The length of the service, the emphasis on its various stages, and the rich symbolism with which each movement of the occasion is invested is exceptional, certainly in Plain circles but also in churches whose thinking and practice is informed by Reformation thought and practice. There is an opulence here that is often lacking in the bleak or perfunctory observances of other traditions. Through participation, Old German Baptist members reencounter the core elements of their spirituality and the essential distinctives of their faith; in the symbolic reenactments, participants renew bonds with their Lord, with the Fraternity, and with one another. And yet there is something more, something beyond. While they do not use it, the term traditionally used in Anglo-Catholic circles to describe eucharistic celebrations as "the mysteries" seems somehow very fitting here.

\section{Ritual Practices}

Attending to the central ritual practices of any group constitutes an entrée to the textured weave of their world - one that is often difficult to convey in words alone. Appreciating the nuanced meanings underlying ritual practices is also significant in building an understanding of any group. Ritual, as Bell $(1997,237)$ reflects, plays a significant role in structuring reality for any group. She reflects on its significance in "the self-definition of communities." Victor Turner's (1990) seminal thinking draws from the world of anthropology and additionally highlights the import of ritual space in the definition of boundary, and hence of identity, in a world increasingly characterized by lack of borders. More importantly for our purposes, ritual has a vital place in representing and demonstrating a group's deep meanings and priorities. While these are central, they are not always 
easily accessible, or expressible in words. Often what is most significant in a group's understanding of the world and of itself lies beyond mere words and is enacted rather than spoken. ${ }^{4}$

Using an autoethnographic and descriptive methodology, this article mines the author's experiences of observing a number of the Old German Baptist Brethren love feasts, weaving these with reflections and comments provided by members themselves to provide readers with a feel for the occasion. It is a foundational assumption of this article that an understanding of the Brethren love feast not only furnishes an encounter with an interesting expression of Plain ritual but more significantly provides an introduction to the distinctive system of meaning that lies at the heart of this group's life and spirituality. The piece proceeds by providing a brief introduction to the Old German Baptist Brethren as a small but significant expression of Plain Christianity. It then introduces autoethnography as a respectful method of social inquiry, positioning it as nested within both postpositivist and narrative research frameworks. Having set this scene, the article then proceeds to introduce the love feast and to detail and explore its various constituent movements.

\section{Plain Christians}

The Old German Baptists form a small but significant expression within the constellation of Plain or Old Order churches. Most such communities trace their heritage back to the Radical Reformation and particularly to the Anabaptist movement of Continental Europe (Bender 1944; Durnbaugh 1958; Estep 1975). As already suggested, the Brethren are distinctive among their Plain peers in that they draw heavily on a Pietist as well as on an Anabaptist legacy, weaving elements of the two streams together in what can be something of an uneasy mix (Kraybill and Bowman 2001).

The Brethren movement emerged in 1708, in Schwarzenau, a village in a then somewhat isolated area of today's west-central Germany. (Cologne and Frankfurt are the largest cities relatively close at hand.) Following the Thirty Years War, the era was one of profound social, economic, and religious upheaval, and there was significant poverty in the area (Durnbaugh 1958; 1997). The emergent group represented a concentrated attempt, in an epoch characterized by warring religio-political hierarchies, to restore a simple yet vibrant expression of authentic New Testament Christianity. In this endeavor, they were significantly influenced by Mennonite associates with a strong heritage in Anabaptism and simultaneously by the influences of German Pietism (Bowman 1995).

Emerging in the late 1600s, Pietism had become an influential force within (and often outside) the Reformed and Lutheran churches of Continental Europe. It had developed as a movement for spiritual renewal, a foil to the increasingly dead orthodoxy and moribund spirituality of the state Protestant churches. Pietism emphasized personal conversion, the need for a life of growing holiness, and a structure of small group meetings for prayer, fellowship, and Bible study to nurture Christian growth. It stressed the transformation of church through spiritual renewal, and of society through the establishment of a network of educational and philanthropic initiatives, as marks of

\footnotetext{
${ }^{4}$ Butler's concept of "performativity" as an active component in the construction and maintenance of identity is a significant additional lens through which to examine ritual (Davis 2008, 62, 187).
} 
lively Christian witness. Pietism emphasized individual spiritual agency, openness to the Holy Spirit's leading, and a certain mysticism. The weaving of these accents with Anabaptism's emphases, particularly its stress on the gathered church community and the collective authority of the latter, continues to be a challenge for the Old German Baptist Brethren. Both streams unite in the group's emphasis on the importance of spiritual experience expressed in practical lived Christianity.

Eventually driven from Europe by vicious persecution, the burgeoning group found refuge in William Penn's experiment in religious tolerance in Pennsylvania (Durnbaugh 1997). In the freedom and wide-open horizons of America, they prospered and grew to become a large, significant - and much later a substantially fractured-movement. The Old German Baptist Brethren represent the most conservative and most numerically significant Old Order expression of the original group. They see themselves as most nearly representing the vision and practice of the original Schwarzenau band (Kraybill and Bowman 2001).

\section{Respectful Inquiry}

Finding a method of social inquiry that is simultaneously respectful and also capable of conveying something of the rich complexity of a group's life and thought, is a challenge. ${ }^{5}$ This article privileges the lens of narrative research - and particularly autoethnography - as a framework which allows for both. ${ }^{6}$ Such lenses demand a respectful approach both to the topic and to the people involved. Both insist on the recognition of the complex nature of any social phenomenon and consequently emphasize tentativeness regarding claims of "complete understanding" or "objectivity." In social inquiry, informed by such postpositivist approaches, the inquirer takes up a learning - rather than a definitive - stance, and one that is focused on exploring with and learning with and from those with whom we interact (Ryan 2015). Both narrative and autoethnographic methodologies allow for the "mixing" of methods - story, recollection, quotes, and historical and conceptual frameworks are woven together in the service of providing a rich description.

\footnotetext{
${ }^{5}$ This article is based on my attendance at many Sunday services and at a number of "love feast occasions," both district events and Annual Meeting observances. It draws heavily on conversations with members and office bearers (elders, ministers, and deacons), as well as with outsiders familiar with the Brethren, their customs, and their rituals.

${ }^{6}$ Narrative inquiry and autoethnography differ from the better-known research methodology of participant observation in a number of significant ways. The former are grounded in postpositivism while the latter can be theoretically based and also be positivistic. Postpositivism explicitly contests notions of ultimate reality, objectivity, and observer neutrality, and it also foregrounds researcher context and reflexivity as essential factors in the research endeavor. Neither are necessarily or explicitly the case with participant observation. Autoethnography also privileges the feelings, impressions, and emotions of the researcher and includes these as significant aspects of both the research "process" and of "findings." In general, both narrative and autoethnography privilege agendas of social justice and the marginalization and "othering" of minority groups. For a more comprehensive discussion, see Walsh and Ryan (2015).
} 


\section{Narrative}

Narrative inquiry foregrounds the importance of story in human life and particularly in the complex process of meaning-making (Walsh 2015). From earliest times, narrative has formed a central component in human processes of living - and especially in communication and in defining (and understanding) difference. The discipline of narrative research recognizes stories as unique conduits-lived and told filters through which humans engage in the projects of building lives, relationships, collectivities, and schemas of meaning-making. Narrative research is a very broad discipline in that it uses stories in a variety of different ways with the aim of wondering, hypothesizing, and communicating around human behavior and assumptions (Clandinin and Connelly 2000). This article is largely constituted by "my story" (interwoven with the reflections and "stories" of others), relating to the experience of observing (and participating in certain elements of) the Old German Baptist observance of the love feast.

\section{Autoethnography}

In autoethnography, a subset of narrative inquiry, researchers present stories of their own experience - and the experiences of others - as part of a subgroup or subculture to which they belong or in which they temporarily participate. In this role, according to Jewett $(2008,72)$, they become "mediums," simultaneously part of two contexts, using their own experiences to describe and to convey a sense of a lesser-known world to a wider universe. Rather than being concerned with notions of objective reality, the autoethnographic writer strives to convey a sense of how things seemed to be in that minority world. Writing about their experiences "their goal is to touch a world beyond the self of the writer" (Jewett 2008, 73). The presentation of such material in an evocative way that moves both head and heart is a significant part of the genre, and a central aim is an increased understanding of those defined as "other."

Unlike traditional scientific modes of research, narrative inquiry resists claims of objectivity. It contends that acts of observation and of analysis are processes vulnerable to a multiplicity of influences that create biased and partial conclusions. The subjectivity of the inquirer is always implicated in what is seen, experienced, and communicated; despite reflexivity and a selfcritiquing attitude being a necessity for the inquirer, bias is always present. In this particular instance, my Irishness, maleness, academic background, and particular life history will materially influence what I notice and how I understand, misunderstand, analyze, and describe. My own experience as a member of the tiny Irish Protestant minority creates bias - and perhaps at times is a benefit too-in seeking to understand the Old German Baptists in general and their observance of the love feast in particular.

\section{Preparation}

As ten o'clock approaches, the chatting groups drift up the meetinghouse steps, men towards open doors at one end and women towards others. Suddenly, the sound of singing is borne through the open window; the drift of movement becomes suddenly quite focused. Inside the building, there is a stark simplicity to the unadorned white walls; through the plain glass windows, the trees and 
fields of the surrounding lush countryside, and its quietly grazing cattle, are clearly visible. Long, uncushioned wooden benches have been pushed close together to accommodate the huge crowd; there must be five or six hundred packed into the meetinghouse today. The lengthy pine table, positioned across the long side of the building, at which the ministers and deacons sit facing each other, has been extended today to accommodate the crowd of visiting officials. Customarily, visiting ministers from "out of state" rather than "local Brethren" will preach this weekend.

As we find seats, the volume and rich harmony of the unaccompanied singing is overwhelming. Members sing very, very slowly, savoring the meaning and the personal application of each word, each phrase, of a hymn. Hymn singing is an important and the sole overtly participative component of the worship for the congregation. Harmonies are spontaneous, traversing far and wide beyond the standard tracks of the more usual four-part standard norm of other churches. This extemporaneity too is significant, described by one elder as "spontaneous worship in which the whole body is engaged." The Old German Baptists do not follow a written liturgy or resort to any form of worship "resource." Today's services will follow a prescribed and time-honored structure. There will be Scripture readings (always from the Authorized Version), a number of hymns, times of prayer, a main sermon, and two or more subsidiary addresses. In this, the first formal service of the weekend, the focus of the sermons is on spiritual preparation for the central focus of the weekend, the evening's four- or five-hour-long love feast observance. Everyone knows exactly what to expect in the structure of the services, and for many attenders there is security and, I suspect, perhaps also a sense of restfulness in such predictability.

Among the Old German Baptists, the love feast is hosted, generally once a year, by each "district" or congregation. It is observed too as a focus for spiritual renewal and unity at the brotherhood's Annual Meeting - that vast concourse when all members are invited to gather at Pentecost, for a long weekend of worship, fellowship, and the transaction of policy and business decisions. District love feasts, however, are central sites where members link with their Lord and with one another. Lasting over a full weekend, elements include several services, communal meals, multiple contexts for visiting and informal fellowship, and an extensive program for the "Youngfolks." Preparatory to the occasion, two district officials visit each member; this is an important rite when members are requested to renew their baptismal commitments and their dedication to the Fraternity. Should either be found wanting, or there be concerns about the individual's standing, a member can be "set back" from the forthcoming Communion until matters are resolved. The visit also serves to check on the spirit of unity within the district. Where this is found to be an issue, it is not unheard of that the love feast be postponed until such concerns are settled. To sit together at the sacred table where unresolved issues or significant division exist would be seen as a contradiction of the core assumptions central to the occasion.

Participation in the love feast is considered vital for the cultivation of devotional life, for fostering deep fellowship, and for the encouragement and nurture of unity across a personally and geographically diverse group. At the outset of a new year, many Brethren will spend time planning the five or six love feasts - often in physically distant districts - that they hope to attend over the 
coming twelve months. While "love feast" is used as a generalized descriptor for a district's weekend observance, the term is more specifically applied to the central core of the occasion, held on the Saturday evening. This consists of a service, often lasting for four or five hours, that includes reflection and preparation, communal footwashing, a light meal (termed "the Lord's Supper"), and the formal exchange of the holy kiss. It concludes with the sharing of the bread and wine of Communion. Preparatory services held earlier that day and Sunday's (usually) two morning services act to frame this central ritual.

To Brethren, participation links them backwards to the agape celebrations of the early church and, more significantly, to the detailed pattern of the Last Supper as described in the Gospel accounts. The occasion also celebrates the sensed links with members unable to be present due to distance or infirmity and also to former participants now gone from the earth, emphasizing what other denominations might refer to as the "communion of saints." Involvement also carries a sense of anticipation, linking participants forward to that ultimate celebration - the heavenly feast of the Lamb. The mystical sense of being surrounded, even being a living part of "that great cloud of witnesses" referred to by the author in the twelfth chapter of the Epistle to the Hebrews, is at times a centrally felt experience for participants. Together with the mixing of formal worship, communal meals, and multiple opportunities for conversation, discussion, and spiritual sharing, these are all vital elements of the occasion. The love feast expresses in formal context a variety of central emphases of Brethren life, giving "form...to the dominant values holding the group together" (Bell 1997, 40). Members maintain and invest considerable energy in the view, despite acknowledging some minor shifts in thinking and practice indicated by Bowman (1995), that the order of the occasion as it unfolds today has not changed substantially since the group arrived in America almost three hundred years ago. Such an ascription of unchanging ritual, and its links to Schwarzenau and early America, as well as conceptual connection to the practices of the early church, particularly to the New Testament, is significant in Old German Baptist ascriptions of selfunderstanding and identity. Levi-Strauss conceptualizes such an aspiration as embodying a reaction to "what thought and myth have done to the world, a(n)...attempt to restore a mindless continuity to experience" $(1963,16)$. The reiteration of ritual process "provides tangible and compelling personal experiences of the rightness and naturalness of the group's moral values. It makes these values the stuff of one's own experience of the world."

\section{Fellowship and Worship}

Shortly after noon, this initial preparatory service concludes. Just before its close, there is a mass exodus of helpers and servers down the stairs to the basement. As doors open and close, the aroma of boiled beef envelops the upstairs congregation like a heavy incense.

A few moments later, descending the stairs to the basement, we are directed to backless benches set at tightly packed trestle tables. Diners are waited on by a phalanx of multigenerational teams drawn from the local district. The cooking, serving, and clearing is achieved with a militarylike precision. Everyone involved knows the duties involved and their particular role in the process. Traditional love feast fare is served at each meal of the weekend: enamel plates of boiled 
beef set atop bowls of broth, plates of bread, and jars of pickles and apple butter are centrally placed on each long table. Diners will help themselves, washing the food down with water or later coffee (and sometimes tea) accompanying slices of pie, or fresh fruit, which constitute the second course of the meal. Each repast begins with prayer and a sung "table-verse." The crescendo of singing is overwhelming in the low-ceilinged basement. As the meal commences, the range of conversational topics that I can overhear is wide-politics, farming prices and policies, internet use (a current issue for the Fraternity). Recipes are being exchanged too, and news of absent family members or friends is being relayed. Neighbors seated on either side of me introduce themselves. Jesse, on my right, a farmer perhaps in his late fifties, chats animatedly, interested to know what I'm doing here. Just before we finish the meal, he excuses himself, reappearing some minutes later with a card, which he places before me. Realizing that I had not known the earlier "table-hymn," he has found the words of the one we will be using at the meal's conclusion. "Jus' so's ya won't feel left out," he mutters quickly. I am touched by the trouble he has taken for my inclusion.

Later, those who have eaten create room for the next relay of diners by making their way outside. Here they engage in active visiting. In one group, the conversation is focused on the difference between Anabaptism and Pietism. I wonder aloud if Pietism's emphasis on mysticism may be a significant part of the distinction. There are a number of nods of agreement. Shortly before two o'clock, we begin to head towards the meetinghouse for the shorter afternoon service. The attendance here is smaller-some have left to attend to farm or household duties, others for some downtime before the lengthy evening love feast service. The young people often have activities at this time too. Walking together, Jesse, my neighbor at the noon meal and part of the later conversation on Pietism, slows his pace. Ultimately, he stops; he has something to say.

"Well..., you know what you said about mysticism?" he enquires. "It kinda made sense."

"D'you think so?" I respond, matching my tone to his.

"My first love feast...I was just a raw-boned country farm boy...but I'd done a bit of living... and I was kinda nervous. It had taken a long time for me to make up my mind to seek baptism... and I'd never felt anything much. I really didn't know if I should be at love feast at all somehow..."

His words trailed off and he paused thoughtfully.

"I suppose I had a lot to feel ashamed about back then...

"As the brethren approached our table to wash feet, I'd taken off my shoes and then my socks and was sitting waiting...watching what everyone else was doing...feeling worse by the minute... actually I just wanted to run...

"Suddenly a brother was kneeling in front of me. He took my feet and began washing...he was just SO gentle. I was looking down at the top of his head as he knelt bending over my feet. I remember his hair was fair and beginning to thin on top.

"Then something real strange happened - everything seemed to change; as I was looking down it was another, different, head there... with full dark hair... 
"And there were other hands, dark brown, work-hard hands, gently-so gently-washing my feet. Then the man looked up. He looked into my eyes...He had these dark, dark brown eyes. They looked so deep into me...it felt like they saw it all...my guilt, my doubts, my fears...

"And then He smiled, so warmly, so lovingly...it was kinda like an embrace. Somehow, I knew it was the Lord...washing my feet! I couldn't hardly believe it-but suddenly deep down I knew this was real. And I knew he...He accepted me!

"And I knew too that all the people around me were accepted too...warts and all."

There was a silence. What could I say? Our eyes met and I nodded; words seemed suddenly inadequate, intrusive.

"That happened nearly forty years ago; nothing like it has ever happened to me again. But it changed me inside. Experiencing that love...that changed me. Maybe that's mysticism?"

"I imagine so, Jesse. Thank you."

I felt as though I had known him for years. We went in to the service together; with different preachers, it was a shorter carbon copy of the morning. The emphasis again was on hearts prepared for the love feast.

\section{Anatomy of the Observance}

For the Brethren, participation in the love feast calls forth both a personal and collective intensity. It is a celebration of common faith and at the same time a reminder and reinforcement of the essential elements that constitute their shared assumptions and experience.

Five main integral sections, each with a dominating theme central to the group's understanding of Christian commitment, make up the experiential core of every love feast:

- There is a central emphasis on self-examination, which is strongly reflected in the Saturday morning and afternoon preparatory services and particularly emphasized at the opening devotions of the love feast itself. This emphasis encourages the individual towards mindfulness regarding their actions, thoughts, and assumptions. For the Brethren, as for Socrates, the "unexamined life" is hardly worth the living.

- The ritual of communal footwashing is a distinctive element at every love feast. Each member participates. Here they enact their commitment to live as servants, not just of their Lord and Master, but also of one another. It underlines the group's emphasis on humility and of the strongly countercultural value of submission - to one another as individuals but also to the collectivity of the brotherhood.

- Each occasion includes a simple shared repast, the "Lord's Supper." This not only recalls the final supper shared by the Savior with His disciples, but it also recalls the agape meal eaten by members of the early church. This common meal speaks of the importance of members' sharing together and of their commitment to one another. It symbolizes the importance of a common 
experience of faith. Further, it looks forward in anticipation to the Marriage Supper of the Lamb in Heaven.

- A ritualized sharing of the holy kiss represents the Brethren's desire to be a distinct, and regenerate community — one that is clearly bounded from the wider world and nonconforming in its assumptions and practices to those of that wider world. It also highlights the importance of unity among members. In keeping with the group's Anabaptist antecedents, nonconformity, unity, and a life of practical lived Christianity are important elements to be expressed in belief, assumptions, and lifestyle.

- The denouement towards which the whole occasion moves is the taking of the bread and wine. Communion is a potent reminder of the believer's participation in the all-embracing experience of God's great love, expressed most centrally in Christ's suffering and death. For participants, communing represents a conscious recommitment, a response to all that such love involves. It emphasizes the willingness of participants to gladly bear His cross and suffering. It is a mystical experience, and one that is beyond easy translation into mere words.

As in a musical symphony, there are distinct movements to the structure of the love feast, the whole constituting a totality of experience greater than the sum of the individual parts. The entirety of the "occasion" draws strongly on the Brethren's Anabaptist heritage, which views the church as a distinct body of adult believers, called out and clearly bounded from the world. It simultaneously emphasizes their Pietist heritage, which privileges the numinous and, in the words of an elder, "the believer's mystical relationship with Christ, which is a union effected in and through love, with the result that the human wills nothing but what God wills." The occasion represents both a celebration of and a catalyst toward the unity of thought and practice, perceived as essential characteristics of membership of God's kingdom.

A quotation from the writings of Alexander Mack, the Brethren's first minister, underlines the continuity of these emphases:

When...the believers gathered in united love and fellowship and had a supper, observing thereby the commandments of the Lord Jesus that they wash one another's feet after the example and order of the Master (John 13: 14, 15). Yes when they broke the bread of communion, proclaimed the death and sufferings of Jesus, praised and glorified his great love for them, and exhorted one another to bear the cross and endure suffering, to follow after their Lord and master, to remain true to all his commandments, to resist earnestly all sins, to love one another truly and to live together in peace and unity - that alone could be called the Lord's supper. (Mack 2003, 62) 
The love feast is lengthy by any standards; it constitutes a highly complex ritual structure with a heavy emphasis on preaching and the more economical exercise of (always extemporaneous) prayer. Participants appear to use the occasion as a form of "liturgical journeying" and as a meditative exercise in which they move between the preaching (and other elements of the ritual process) and their own inner devotional world.

Jeff Bach, director emeritus of the Young Center for Anabaptist and Pietist Studies at Elizabethtown College, Elizabethtown, Pa., comments:

The preaching opens the participants to an awareness of God through the verbal cues of Scripture and hymns and through the spoken commentaries. Instead of making the ritual fit into a compacted, expeditious hour, the whole occasion slows time down in a way that today's Americans rarely experience. The slower, expanded time is "filled" with multiple layers of sensory experience - auditory (e.g., the sound of singing), olfactory (e.g., the smell of cooking beef), visual, tactile, and taste-all directing participants to connect with the sacred meaning of the events.

The verbal cues, when done well, reinforce the meaning of the actions of the love feast. All work together almost as obstacles or hurdles that decelerate listeners, focusing their attention - these become gates of meaning that participants "pass through" into each segment of the love feast. The approach represents a contrast to the liturgical strategies of other Western traditions; it probably has more in common with the approaches of the Greek and Russian Orthodox churches. Of course, the effectiveness of the "slowings" and "fillings" of time with sacred meaning will vary for different individuals.

\section{The Love Feast}

Later, the worshippers reenter the meetinghouse, following a short break, for the weekend's core ritual of Saturday evening. The interior presents a transformed aspect. Local members have been busy; instead of facing the front, the pews have now been positioned around long, trestle-like tables covered in white linen cloths. (Some pews are actually constructed in such a way that they can be transformed into serviceable tables, the erstwhile backs serving as tabletops, with a minimum of effort.) All participants will be seated at tables. The overflow of worshippers occasioned by the now-reduced seating arrangements upstairs will be accommodated around the tables, used earlier for the midday meal, in the basement. Only a small corner designated for observers (usually unbaptized young people and nonmember visitors) has been left unaltered in the meetinghouse. There is usually quite a crowd of the former, some themselves contemplating baptism; the number of other nonmembers or visitors is usually small.

As the building fills, I find myself, positioned in the observers' area, in a pew directly behind a row of men seated at a white-clothed table. Another seat-full of men, mixed with a few small boys, sit facing them (and me) across the table's surface. Throughout the large room, several 
hundred sisters and brothers (as female and male members respectively are termed), segregated by gender, sit on the hard seats at similar white-clothed tables. A huge silence fills the upper room; there is no conversation and, of course, no music. The atmosphere is redolent with expectancy and reverence. Even the small boys opposite me are still, but their eyes are alert, darting here and there, sparkling with a sense of anticipation. One of them, suddenly catching my eye, gives me a big wink.

Many of the men in my line of vision are reading their black-bound Bibles, open on the tables before them. I assume (but cannot, from this vantage point, see) that the same is happening on the women's side of the meetinghouse. I shift uncomfortably on my hard seat, uneasily aware that the long service hasn't as yet even started.

Unexpectedly there is the surreal sound of rich, disembodied singing. I look around; no one seems surprised. Am I imagining things? Or experiencing a moment of Pietistic mysticism? Then a minister at a central table rises, announces a hymn number and then begins to line its first verse. As a deacon raises the tune, I realize that the service in the basement has commenced just before ours upstairs; I was hearing the opening hymn from below. As the meeting proceeds, I respond quietly to the hymns and prayer, and then to the address during this initial service of selfexamination. Before this section of the evening concludes, each participant is instructed to look deep within and to make their own silent, prayerful response. These are then gathered up in audible prayer and in the recitation of the Lord's Prayer.

\section{Footwashing}

There is an imperceptible shift as we embark on the next stage of the service, the solemn rite of footwashing. A hymn is announced, lined, the tune raised, and we sing:

When Jesus Christ was here below

He taught His people what to do;

And if His precepts we would keep,

We must descend to washing feet.

(Taylor 2011)

The slow, resonant singing, interspersed with the sonorous lining, creates a deeply meditative effect. As we move into the second verse, a group of deacons, with other designated brethren, rise and make for the doors to the basement. Again, the heavy aroma of boiling beef descends upon the crowd. The men return moments later with pails of water; they leave one at each table. They leave again and then return, this time equipped with enamel basins and piles of white towels. A basin and towels are carefully placed at each table end. Then a deacon fills each basin with water.

The Old German Baptists are intensely practical; the rite of footwashing is not just symbolic ritual. It is intended to model members' attitude to others. 
An elder explains:

Footwashing represents what our attitude should be to each other-the posture of kneeling humility, the gentleness of touch. But it is particularly linked to the pre-communion office bearers' visit to each member. Sometimes there are difficult issues to be approachedin either direction. Both the visiting Brethren and the visited members need to adopt the approach exemplified in footwashing: listening with humility, responding with gentleness and concern. The approach, attitude, and words need to be grounded in the postures of the footwashing. And this should be the model of all our dealings with each other.

After another hymn, words from the thirteenth chapter of John's gospel, describing the opening events of the Holy Thursday supper in Jerusalem's upper room, are read. Other than the minister's voice, the only other sound is the riffling of pages as members turn to the portion in their Bibles. Then another minister rises to give an exposition of the passage: "He washed the disciples' feet. That's what Jesus did when he was facing torture and death. That's how important He felt footwashing was... and all it symbolizes." The preacher's voice is heavy with emotion, conviction.

Despite the warmth of the autumn evening, every man wears a high-collared black suit coat, buttoned to the neck; only the glimpse of white shirt appearing at the neckline relieves the somber dress. Opposite me, a teenage lad shifts on the hard bench; he can't be more than fifteen. His face is pale with concentration, his eyes closed in prayer. There is another shift in the service; the last sermon concluded, the officiating minister announces, "A brother will rise and speak to us as we begin to wash feet."

As the designated preacher commences, I am fascinated to watch men rising in couples throughout this side of the meetinghouse. Standing at the end of tables, they assist each other in removing their coats and in tying white toweling aprons around their middles. Having washed and dried several feet, the couple changes places with another duo. The same is happening among the women. As the sermon continues, the men in front of me begin removing their shoes and socks. Leaning forward slightly, I watch as each man's feet are tenderly, almost reverently, taken and washed by one brother and then gently dried by his partner. The process is almost a caress. Then to each man there is a brief word of encouragement, a handshake, and then the salutation-that kiss on the lips. There is neither rush nor embarrassment; instead there is a sense of holy connection. Suddenly I see Jesse; his eyes meet mine across the crowded room and I become conscious of the preacher's actual words: "Tonight we're washing feet; tonight we meet the Lord. But that's the easy part. But every day-it's His attitude we need to display-submission-that's the hard part. But that's what the Savior did." Perhaps he's indicated a clear overlap between Pietism and Anabaptism.

Acceptance, yieldedness - a form of the Gelassenheit identified by Kraybill (2001) and elaborated by Martin (2007) — is central to the assumptive world of Amish and other Plain groups. 
The Old German Baptists use the term "submission" to describe and somewhat elaborate this foundational principle; it is central to their spirituality and life. For members, submission encompasses their attitude to God, to the Fraternity, and particularly to the decisions of Annual Meeting. Mutual submission, member to member, is also encouraged. Both principle and practice are profoundly at variance with the individualistic discourses of Western society and its emphasis on the dominance of the individual and their entitlements. Submission in Brethren thought encapsulates the surrender of individual rights in response to the greater good. It is a challenging concept.

And for me, there is a particular issue here. The appalling abuses (sexual and otherwise) perpetrated by the priests of Roman Catholicism, particularly prevalent in Ireland and ignored by their hierarchy, were enabled and validated by the submissive attitudes of church members. And indeed by the noncritical attitudes of Irish society as a whole. The Irish Catholic Church maintained its internal unity through the enforced submission of dissenting voices. It did so at a truly frightful price. I have worked with some of its victims. Submission has complex connotations; I am left with questions.

The Brethren's (fairly) democratic structures and attitudes strive to resist the explicit (or implicit) power structures of other denominations. This is bolstered by the centrality of their practice of critical personal reflection, which contests notions of individual rights, personal empowerment, and social success. It contests, at least in theory, institutional power. "Submission is difficult, it's a practice... a responsibility. It involves real honest questioning of yourself. It means listening, really hearing the other," declaims the preacher. "The individual, the group with more power, has to listen carefully, to back off, to be compassionate. To feel your way into the other one's shoes...even when-particularly when-you most disagree." It's a directive toward a different way of being, one that implies possibilities for power abuse certainly. Does the emphasis on self-critique provide a balance? I am not convinced.

It could be hypothesized that the central emphases on submission would produce a predominance of magnolia-shaded personalities. Instead, however, Brethren districts are full of strong, creative characters - both men and women. "We need strong personalities," maintains a minister. "But we need them to be pliable and open too." The emphases on submission, strength of character, and humility, balanced with conviction and an informed view, is acknowledged as a challenge. At its best, it seems to distill into a respectful attitude rather than a blind obediencean ability to listen carefully, prayerfully, to one another-but not necessarily without critical awareness. When unanimity of view is achieved regarding contentious issues (as regularly happens, particularly at district or Annual Meetings), it is seen as being achieved through the clear operation of the Holy Spirit's influence. 


\section{The Lord's Supper}

Later, during the singing of another hymn, the tables are tidied. Bowls, towels, and aprons are removed, disappearing downstairs by a retinue of men. The men reappear minutes later, this time with cutlery and mugs and enamel coffee jugs filled with water. Piles of sliced bread are placed on each table, and I know that shortly plates of meat atop bowls of broth will be placed alongside the bread. This meal is an integral part of the evening's worship. When it is served, it will be eaten in silence as participants meditate on the nature and privilege of shared faith, on the Marriage Supper of the Lamb in Heaven.

Another minister is speaking now: "How we think of each other makes all the difference. If you turn the eye of negative scrutiny upon me, I will faint. We need to see the qualities, wonderful qualities, in the other...we need to care for each-love each other-in the way that God loves; that builds each other up." His words constitute a commentary, contribute another layer to his predecessor's words. The Brethren's practice of having a number of sermons following from and building on each other, at its best, develops a topic in a layered way, each speaker bringing their own perspective and contribution - and at times an idiosyncratically refreshing viewpoint.

There is the sound of movement; it is customary for the unbaptized youth to leave at this stage for their own supper arrangements - at McDonalds or a local gas station-returning later. This is my signal to move too; I feel in my pocket for my host's car keys. A packed supper has been left for me in their car. I leave quietly, as the supper is laid on the tables; it will be eaten in silent meditation. A few moments later, I eat my supper in the car. It feels strange; simultaneously, I am excluded from and yet, strangely, outside the walls of the meetinghouse, included in a holy supper.

Half an hour later, I hear the sound of singing; the congregation is embarking on the most solemn section of the evening's proceedings, the exchange of the holy kiss and then the taking of the bread and wine of Communion.

\section{Communion}

The bread and wine for Communion are still made in Brethren homes, and these preparations (including the district visitation, the making of food, and the communal readying of the meetinghouse) are viewed as integral parts of the love feast process. The making of the Communion bread and wine has a sense of particular significance. The bread is prepared and baked at a gathering that includes church officials, their wives, and a number of other members. The traditional unleavened blend of white flour, shortening, and milk or cream to bind and moisten is mixed and rolled into large squares and placed onto baking sheets. It is then scored into strips with a knife or pizza cutter. Each serrated strip is often pierced by a three- or five-pronged fork, symbolic either of the Trinity or of the five wounds of Christ. The sheets are then baked.

The wine is prepared, fermented, and ultimately siphoned and resiphoned off by one or two brothers. Both leaven-free bread and fermented wine are seen as symbolic of purity. Made from wheat and grapes (both often grown on members' land), the preparations are occasions of fun, communal engagement, and spiritual reflection. The weaving of the holy and the common is a significant emphasis in Brethren life. 
A deacon's reflection:

The bread and wine are always central to Communion. There have been wide differences in cultural contexts, in beliefs and practices, throughout history and throughout the differing expressions of Christianity. But these two elements are always at the core. They have been at the center of Christian worship down all the centuries, since Jesus took that Last Supper with His disciples. The bread and wine are the common elements - the fruit of the earth and the work of human hands. They ground us. They unite us. They divide us. It's so real.

As I take my seat again, the tables are being cleared of the remains of the supper. Then, in a deeply symbolic gesture, the white tablecloths are turned over; no trace of leaven is to remain to pollute the table. The unleavened bread and fermented wine all speak of purified substances. Members are again reminded that there must be no unacknowledged, unconfessed sin in their lives as they approach Communion. As we sing again, a group usually consisting of the older ministers and deacons enters from the kitchen area bearing the bread and wine for the Communion service. I don't at first realize that the heavy package, loosely swathed in linen, is the stack of bread sheets. The wine is contained in decanters and in large glass demijohns for refilling; plain metal cups for the distribution accompany the latter. All are placed on the ministers' table. Then excerpts from Mark's gospel, chapter 14, or John's gospel, chapter 19, are read. While a sermon is preached focusing on the gospel account of the crucifixion, the officiating minister is occupied in unveiling the square stack of bread sheets. He takes each sheet, then carefully breaks it along its serrated markings, creating dozens of long bread sticks, building them into a large, square stack of crisscrossed strips.

Some of this evening's participants appear to be listening carefully to the preacher. The eyes of others are moving back and forth, focusing on their Bibles or on the minister as he parts the bread. Others seem preoccupied with their own thoughts; perhaps some are caught in inner visions of Calvary. My eyes are drawn to the wine, glowing richly red in its glass containers. Words from the small black hymnbook come back to me:

Gay mirth shall deepen into joy,

Earth's hopes grow half divine,

When Jesus visits us to make

Life's water glow as wine.

(Clarke 2011)

There is now a pause, a kind of parenthesis in the flow of the Communion service, for the sharing of the salutation. To the gospel accounts of the Last Supper, the Brethren have added a ritualized enactment of the holy kiss. In the context of the love feast, it becomes both an independent ritual and simultaneously a very central component of Communion. Strictly reserved 
for members, the holy kiss either here or in everyday greeting is a direct response to the Apostle Paul's admonition in his Epistles to the Romans and again to the Corinthians "to greet each other with a holy kiss." Male members exchange the salutation only with men and women with women; it is viewed as qualitatively different to all other greetings:

The kiss of friendship may bind, but the kiss of holy love unites. The passion of holy love can only emanate from God and is to be found in the hearts of all His children. (Doctrinal Treatise 2003, 41)

The officiating minister has begun to speak again, focusing this time on the significance of the holy kiss. "The salutation symbolizes the great love of God and of His Son, our Savior...for us. It symbolizes the love we have...the love we should always have...for one another. Both are manifested in the holy kiss. The passing of the kiss this evening...it doesn't just symbolize the relationships between us...it reignites it." The ritual exchange of the kiss, or "the salutation" as it is termed, has another function both at the love feast and when it is used in nonliturgical greetings among members. It demarcates boundary, clearly indicating those who belong and those who exist outside the fold (Bach 2003, 82).

The presiding minister turns to the elder sitting on his left and kisses him gently on the lips while simultaneously clasping his right hand. This salutation is passed down the table until the last brother at that table crosses to another table and passes the greeting to the first man seated there. The latter in turn passes the salutation down that table and so on to the next table until the kiss has been passed throughout the men's section in an unbroken chain. Ultimately, the last recipient crosses to the elders' table and returns the salutation to the initiating minister. While the salutation is being passed among the men, the presiding minister has crossed to the sisters' tables; he passes the "right hand of fellowship" to his wife. She in turn passes a kiss and handshake to the sister seated on her left who, in turn, passes both to the woman next to her and so on until all the participating sisters have shared the greeting. The last sister in the room to be greeted leaves her table, crosses the room and passes the kiss back to the presiding minister's wife, who initiated that circle. The greeting has been exchanged in two unbroken circles including all the participants in the evening's worship.

What the Brethren refer to as the "bread and cup communion" is probably the element of the whole evening most familiar to members of other Christian denominations. In common with most churches with roots in the Reformation tradition, Communion is seen as commemorative, with no physical change taking place in the bread or wine. However, to suggest that the ordinance is "purely commemorative" is perhaps reductionistic. The Brethren invest each element with an unusual intensity of symbolic meaning and a depth of mystical significance (Mack 2003, 6). As in many other churches, Communion is certainly considered to be a means of grace (Aronson 1996, 
7). ${ }^{7}$ The address preceding the passing and reception of the bread and the cup frequently opens with such words as "I am going to paint a word picture for you of the sufferings of the Savior." Such a focus is pure Pietism.

The minister continues, focusing in detail on the Lord's suffering and death, making the events of Calvary as real as possible for the hearers. "May we allow ourselves to be crushed and blended into His body, as the grain was crushed and blended into this bread." He is referring to the individual being blended into the Lord's body — and into the body of believers. To the Brethren, they constitute the same reality: to be at one with the Lord is to be at one with the Fraternity and vice versa. There is both a horizontal as well as a vertical emphasis to Brethren spirituality. Submission is core; to suffer is to identify with the Savior.

An older minister speaks of the relevance of submission to suffering, which for him is central to the ordinance:

My old dad relished a brother preaching of the sufferings of Christ; we base our hope in that we ourselves can share in that suffering. The Apostle counted it a joy to suffer for Him; he teaches that if we suffer with Him we can be glorified with Him. That's the basis of our Christian joy-our hope. Our emphasis is on being a little more involved in those sufferings. All our sufferings are opportunities for a little glimpse of how He felt. This shifts our attitude; we are no longer so invested in being happy...it's ok if we're not.

The minister prays, giving thanks for the ordinance and seeking that the bread before him be set aside for the sacred, commemorative use of the evening. Then he takes a stick of bread from the pile before him, reading from the Apostle Paul's account of the early church's Communion service recorded in 1 Corinthians, chapter 11. Turning to the elder on his left, he breaks off a piece, giving it to him with the words "Beloved brother, the bread which we break is the communion of the body of Christ." He then hands him the remainder of the bread stick. The latter, having placed his fragment on the table before him, takes the stick and breaks a piece for the elder beside him, then hands him the stick and so on down that table. Following this, ministers rise, taking the sticks of bread to tables throughout the meetinghouse.

\footnotetext{
${ }^{7}$ Aronson (1996) contends that for members of the OGBB, the Communion service and believers' actions in taking the elements enfold four particular meanings for members of the Fraternity:

- The unleavened bread and fermented wine are symbolic, a potent reminder of Christ's sacrificial purity made on behalf of sinful men.

- The breaking of the bread and the pouring of the wine represent the Savior's broken body and the shedding of His blood-His redeeming death and sacrifice.

- Partaking of the Communion represents the believer's mystical participation in the Lord's atoning sacrifice and of the presenting of their own bodies "as a living sacrifice" (Romans 12:2).

- The Communion speaks both of future resurrection for believers but also of the reality of present suffering and of the identification with the Savior in that suffering.
} 
A group of younger men in my line of vision sit quietly, waiting for the distribution of the bread. Some are reading their Bibles. Others have their eyes closed in silent prayer. A minister approaches the table nearest to me holding a handful of the Communion bread sticks. John, who I met at the noon meal earlier, is the first man on the left side of the table. The minister stands beside him. He breaks a piece off a bread stick and hands it to John, repeating the words, "Beloved brother, the bread which we break is the communion of the body of Christ." John takes the generous fragment and places it on his Bible, open on the table before him. The minister then gives him the remainder of the stick, and John turns to the man sitting on his left and breaks a piece off for him, repeating the minister's words. In Brethren terminology, he is "communing” his neighbor, enacting, it appears to me, in an unusually practical and explicit way, the Reformation doctrine of the "Priesthood of all Believers" Then John hands his neighbor the remainder of the stick. The process continues until the bread has been broken for each man at the table.

In her comments on a recent love feast occasion, a sister writes:

Did you ever hold a piece of communion bread and feel how similar it feels to a dead body? Or sip the wine and feel the similarity to warm blood? Not that I believe it truly is His body and His blood as do some, but it's the representation of it. And once it is taken within... How much more we realize we are truly a vessel holding Him. Thinking of that must alter how I conduct my life. Oh, the depth of His sufferings for us... And what do we suffer for him?

The communing is being repeated throughout the meetinghouse, the only difference being that a minister, rather than her neighbor, breaks the bread for each woman. Watching, I realize that the bread sticks are never finished; as a stick is coming toward its end, it is replaced by a fresh one; the remainders are kept to be distributed then (or the next day) to the children.

The only sound is the footfall of the black-suited figures on the bare boards of the floor as they move from table to table. Nothing is rushed. There is a sense of intimacy, as, heads bowed together, duos of members commune each other; again, I am conscious the "priesthood of all believers" is being honored in practice in a way foreign to many of those churches who most cherish the concept. Here the meaning of this sacred rite is not just in the consuming of the emblems. It is also in the breaking and in the sharing of the bread to, and with, each other. The familiar words of the Church of Ireland's Communion Service rise unbidden to my mind:

The body of the Lord Jesus Christ...broken for you. Take and eat. Remember that Christ died for you. And feed on Him in your heart by faith, with thanksgiving. (Book of Common Prayer 2004, 219)

Slowly and reflectively, members eat in silence. I have rarely encountered such a deeply personal and yet communally interconnected Communion service. 
It is strange to be barred, yet I have a sense that here "close communion" is not primarily a statement regarding the unacceptability of outsiders. Instead, it seems to speak of a symbolic ritualizing of the depth of connection among members. Coming from a tradition where "all those who love the Lord, or who want to love him more" are invited to the table, it would be easy to become fixated on a sense of exclusion. Perhaps in this situation there is another invitation: First, to reflect on how we are all actively (or passively) implicated in the creation of boundaries that divide, or create "the other"; and second, to reflect on how to make this different form of "participation" meaningful. Preempting the passing of the wine, the words of Isaac Watts (1933), that much-loved writer with roots in English Puritanism, rise in my mind:

See from His head, His hands, His feet, Sorrow and Love flow mingled down.

Did e'er such Love and sorrow meet,

Or thorns compose so rich a crown.

...Love so amazing, so divine,

Demands my life, my soul my all.

When all have communed, after some minutes of silence, the minister takes up the reading of the Apostle Paul's first letter to the Corinthians, chapter 11, again: "After the same manner also He took the cup..." There is a prayer of thanks and the wine is distributed. This time, groups of two elders wait on the tables; one carries the cup, one the glass decanter from which it is constantly refilled. The cup is never allowed to empty; God's mercy and bounty are never exhausted. Brothers commune each other, passing the cup, an elder refilling it as necessary. Each sister is communed by an elder. In every instance, the communing is accompanied by these words: "Beloved brother/sister, this cup of the New Testament is the communion of the blood of Christ." The sharing of the wine is accompanied by the singing of hymns.

A minister concludes:

For me there is an important emphasis in how the bread and wine are taken. There is silence while we pass the bread as we think of His sufferings. Then we sing while we pass the cup, rejoicing in His victory. It feels like participating in the triumph of His Resurrection.

When all have communed, the remains of the wine are returned to the central table. After a short silence, the presiding minister rises: "One time more we have been privileged to sit at the Lord's Table..." he begins. Then everyone rises as he offers a prayer of thanks. There are announcements followed by a simple dismissal and a reminder of the times of the services the next day. The Old German Baptists never use a blessing or benediction; that would exalt some in a Fraternity that favors equality. 
The rising volume of chatter, usual at the close of other services, is curiously muted this evening. The huge crowd goes quietly out into the night as, long years ago, did another group. They leave silently, as if their minds are still preoccupied with sacred things; slowly, as if reluctant to leave this sacred space.

The young people are left behind to do their accustomed job of clearing up and setting the meetinghouse to rights for tomorrow.

Back at my hosts' home, I am mildly horrified at the prospect of supper and more chat; my brain is already awhirl with the day's events - with conversations and personalities. But everyone else seems energized, all set for food and discussion. Perhaps this betokens a certain release from the high levels of concentration invested in the evening's service. And it's well after eleven o'clock; that doesn't trouble me-but I sense we'll need to be astir by six o'clock to be in time for tomorrow's early-morning service, and that doesn't particularly suit my Irish internal clock! Rightly interpreting my facial expression, one brother, smiling quietly, laughs and says, "We don't reckon on getting too much sleep over the love feast weekend!"

Everyone's appetite for conversation, stories, and discussion of the day's events and sermons is undimmed. As we talk, one man becomes quite visibly moved as he speaks of current strains in the Fraternity; there is a divergence of view on internet usage. Ultimately, he weeps openly, grieved not so much regarding the internet issue, but for what he views as lack of unity-and a lack of respectfulness in the expression of divergent views. For him this indicates the want of a submissive spirit and constitutes a threat to, and a contradiction of, the core principle of unity, the heart of Brethren life. His tears, particularly following so closely upon rising from the table of holy ordinance, emphasizes, as little else could, the significance of unity and submission as essential elements of the Brethren's assumptive world. To be a privileged onlooker-perhaps more accurately a trespasser - at such a moment of intimate encounter constitutes the final component of a memorable day. For me it seems to encapsulate both the strengths and weaknesses of the Fraternity's life, that constant pull between individuality and collectivity. This is at the core of their nonconformity to the dominant assumptive world of Western society.

\section{Sunday}

Usually, but not invariably, Sunday morning commences with a service at seven o'clock. This has its origins in a time when travel was difficult and household accommodation limited. Deacons needed to be on hand to start preparations for the communal breakfast, and they and an "overflow" of helpers and visiting members slept in rudimentary "dormitory style" space, usually in the meetinghouse loft. For these men, it seemed appropriate to start the day with an act of worship. Now institutionalized in many districts as part of the overall weekend, it is attended by many members.

This short service is followed by the communal breakfast for all and then, around nine thirty, by the concluding service of the weekend. It is similar to any usual Sunday service, except that the 
focus of the preaching tends to "gather up" the core themes that have emerged over the weekend. And there is an emphasis on parting and on farewell wishes, perhaps sourced in times when living was a hazardous business, life expectancy short, and journeys fraught with many dangers. Ultimately the long concluding service closes with thanks to all, announcements, and a dismissal. The service is followed by the final communal noon meal and afternoon activities for the "Youngfolks"; often a local school gymnasium and facilities have been rented for the occasion. Some older members participate as enthusiastic spectators at these events. The young people seem

to experience this as positive - perhaps it provides them with an enhanced experience of identity and community involvement. Boys and girls, younger and older, members and nonmembers alike, engage with enthusiasm in games of volleyball and basketball. The long dresses and prayer coverings of girl members seem to create little difficulty in vigorous participation. Later there will be pizza, table games, and traditional circle or "parlor" games.

Earlier, after the communal lunch, many members will have dispersed, leaving for home. Others will continue visiting in the area. Informal supper plans and continued social engagements are very much part of the remainder of the day and for some days to come.

\section{Conclusion}

The love feast is core to Brethren spirituality; its emphases reflect Brethren understandings of Christian commitment, of worship, and of the almost mystical nature of the bond that exists among members. A number of other Plain groups including the Brethren in Christ, the Old Order and other associated River Brethren, as well as some conservative Mennonite groups, also observe the love feast. A few non-Plain denominations, including the Moravians and a small number of groups with their roots in conservative Methodism, also observe services that they term "love feasts." These are, however, characterized by a variety of procedures and express a widely varying range of emphases. Indeed, a comparison of the love feast as observed by the Old German Baptists, with its emphasis on procedural complexity and depth of symbolic meaning, and similar engagements of other (and perhaps not only) Plain groups, while outside the focus of this article, would constitute a useful study.

Anabaptists have tended to emphasize "the communal and collective meaning of this sacred ritual, rather than viewing communion as an individualistic transaction between God and a believer" (Kraybill 2010, 52). A Pietistic approach was traditionally more personal, foregrounding an individualistic encounter with God through reconnecting with Christ and His redemptive sufferings. In Old German Baptist understandings, both emphases are woven together in a multitextured tapestry. In the love feast, encountering afresh the mystical nature of the relationship with Christ as well as that with fellow members is not just restated but repeatedly reenacted. The demands of a life lived in unity with the Brethren's shared understandings of the Christian life is a thread that runs through the whole occasion.

All the events of the weekend engage participants in a range of processes inviting spiritual reflection, deepened commitment, renewed fellowship, and the reinforcement of the Brethren's understanding of discipleship. The distinctive emphasis on the church as a clearly defined entity, 
an internally coherent and disciplined body clearly bounded in its thinking, practices, and assumptions from the world draws heavily on an Anabaptist heritage. This weaves with a certain mysticism, informality, and deep personal devotion characteristic of Pietisic thought. Both streams emphasize a transformed life expressed in an emphasis on holiness of attitude and behavior.

Days later, waiting to board the plane that will bring me home to family, friends, and work in Ireland, I reflect on the experience of the love feast. I wonder about the challenges that its multifaceted experience constitutes for my own faith. I reflect on the rampant secularism of Western society and how an Old German Baptist Brethren perspective constitutes a visible resistance to such trends. At times their uncompromising attitudes to Christian life produces individuals of a narrow severity and limited outlook. But often such convictions express themselves in a creative "gentle, orderly people of unimpeachable integrity and clear personal identity" (Lehman 1976, 163). Many are distinguished by a marked degree of perspicacity, exceptional personal color-and profound spiritual commitment expressed in everyday living. And the realities enacted in the observance of the love feast are seen as central to such lived experience. Ramirez summarizes its impact for him:

...love feasts have been the highpoint of my Christian experience. The memories of Christ's presence at the table are sharp. I have seen fathers weep as their sons washed their feet at the "first" communion. I have seen the shabbily dressed, the mentally ill, the physically handicapped sit at the table as equal brothers and sisters. I have washed feet with black, brown, and yellow all at the same table in the same service.... This is where belief and action meet. This is where the mundane converts to the holy; the broken to the whole, the sick to healthy... (Ramirez 2000,112)

\section{References}

Aronson, K. E. 1996. "The Love Feast of the Old German Baptist Brethren in Kansas." Old Order Notes 14 (Fall): 7-54.

Bach, J. 2003. Voices of the Turtledoves: The Sacred World of Ephrata. University Park, PA: Pennsylvania State University Press. https://doi.org/10.13109/9783666558276

Bell, C. 1997. Ritual: Perspectives and Dimensions. Oxford: Oxford University Press.

Bender, H. 1944. The Anabaptist Vision. Scottdale, PA: Herald Press.

Book of Common Prayer. 2004. Dublin: Columba Press.

Bowman, C. 1995. Brethren Society. Baltimore: Johns Hopkins University Press.

Clandinin, D. J., and F. M. Connelly. 2004. Narrative Inquiry: Experience and Story in Qualitative Research. San Francisco: Jossey Bass.

Clarke, F. 2011. "Dear Friend, Whose Presence in the House." In A Collection of Hymns and Sacred Songs, no. 511. Walnut Creek, OH: Carlisle Printing. 
Doctrinal Treatise. 2003. Englewood, OH: The Vindicator.

Davies, B., ed. 2008. Judith Butler in Conversation: Analyzing the Texts and Talk of Everyday Life. New York: Routledge.

Durnbaugh, D., comp. and trans. 1958. European Origins of the Brethren: A Source Book on the Beginnings of the Church of the Brethren in the Early Eighteenth Century. Elgin, IL: Brethren Press.

Durnbaugh, D. 1997. Fruit of the Vine: A History of the Brethren, 1708-1995. Elgin, IL: Brethren Press.

Estep, W. 1975. The Anabaptist Story: An Introduction to Sixteenth-Century Anabaptism. Grand Rapids, MI: Eerdmans.

Friedmann, R. 1949. Mennonite Piety through the Centuries: Its Genius and Its Literature. Goshen, IN: Mennonite Historical Society.

Jewett, L. M. (2008). A Delicate Dance: Autoethnography, Curriculum and the Semblance of Intimacy. New York: Peter Lang Publishing.

Kraybill, D. 2001. The Riddle of Amish Culture, rev. ed. Baltimore: Johns Hopkins University Press.

Kraybill, D. 2010. Concise Encyclopedia of Amish, Brethren, Hutterites, and Mennonites. Baltimore: John Hopkins University Press.

Kraybill, D., and C. Bowman. 2001. On the Backroad to Heaven: Old Order Hutterites, Mennonites, Amish, and Brethren. Baltimore: Johns Hopkins University Press.

Lehman, J. 1976. The Old Brethren. Elgin, IL: Brethren Press.

Levi-Strauss, C. Structural Anthropology. New York: Basic Books 1963.

Mack, A. 2003. "Rights and Ordinances." In The Complete Writings of Alexander Mack, edited by W. Eberly, 43-105. Winona Lake, IN: BMH Books.

Martin, D. 2007. Distinctive Teachings of the Old Order People. Wallenstein, ON: Vineyard Publications.

Ramirez, F., comp. 2000. The Love Feast. Elgin, IL: Brethren Press.

Ryan, A. B. 2015. "Introduction." In Writing Your Thesis: A Guide for Postgraduate Students, edited by $\mathrm{T}$. Walsh and A. Ryan, 2-25. Maynooth, Ireland: MACE.

Taylor, J. 2011. "When Jesus Christ was Here Below." In A Collection of Hymns and Sacred Songs, no. 306. Walnut Creek, OH: Carlisle Printing.

Turner, V. 1990. “Are There Universals of Performance in Myth, Ritual, and Drama?” In By Means of Performance: Intercultural Studies of Theatre and Ritual, edited by R. Schechner and W. Appel, 8-18. Cambridge: Cambridge University Press.

https://doi.org/10.1017/CBO9780511607806.003

Walsh, T. 2015. "Using Narrative Inquiry." In Writing Your Thesis: A Guide for Postgraduate Students, edited by T. Walsh, and A. Ryan, 117-134. Maynooth, Ireland: MACE.

Walsh, T., and A. Ryan, eds. 2015. Writing Your Thesis: A Guide for Postgraduate Students, Maynooth, Ireland: MACE. 
Watts, I. 1933. "When I survey the wondrous cross." The Methodist Hymn Book, no. 182. London: Methodist Publishing Company. 